PRIMANOMICS : JURNAL EKONOMI DAN BISNIS - VOL. 17. NO. 2 (2019)

Versi Online Tersedia di : https://jurnal.ubd.ac.id/index.php/ds

| 1412-632X (Cetak) | 2614-6789 (Online) |

\title{
Analisis Rasio Likuiditas, Solvabilitas, Profitabilitas Untuk Menilai Tingkat Kesehatan Perusahaan Pada Pt. Harapan Jaya Lestarindo Tangerang
}

\author{
Tutut Nurul Kharimah \\ Sutandi \\ Universitas Buddhi Dharma, Banten, Indoensia
}

\begin{abstract}
ABSTRAK
Pada saat ini pentingnya akuntansi keuangan makin disadari oleh setiap perusahaan. Selain untuk mengathui keadaan keuangan suatu perusahaan juga dapat digunakan sebagai pertimbangan untuk mengambil suatu keputusankeputusan ekonomi oleh suatau perusahaan salah satunya perusahaan jasa Rasio menggambarkan suatu hubungan atau perimbangan (mathematical ralationship) antara rasio ini akan dapat menjelaskan atau memberi gambaran kepada penganalisa tentang baik atau buruknya keadaan atau posisi suatu perusahaan terutama apabila angka rasio tersebut dibandingkan dengan angka rasio perbandingan yang digunakan sebagai standar. Hasil perhitungan rasio likuiditas yaitu current ratio ,test acid ratio dan cash ratio posisi keuangan dikatakan likuid. Rasio solvabilitas yaitu rasio hutang dengan modal sendiri dan rasio hutang dengan aktiva posisi keuangan perusahaan dapat dikatakan solvabel. Rasio rentabilita yaitu gross margin ratio,net margin ratio dan rate of ROI maka perusahan dikatakan profit. Dan hasil penilaian atau analisis tingkat kesehatan perusahaan maka perusahaan dikatakan sehat.
\end{abstract}

Kata Kunci : Laporan keuangan, Analisa rasio, Tingkat Kesehatan Perusahaan. 


\begin{abstract}
At present the importance of financial accounting is increasingly recognized by every company. In addition to understanding the financial condition of a company can also be used as a consideration to take economic decisions by a company, one of them is a service company The ratio describes a relationship or balance (mathematical ralationship) between these ratios will be able to explain or give an illustration to the analyst about the good or bad condition or position of a company, especially if the ratio is compared with the ratio of the ratio used as a standard.The results of the calculation of liquidity ratios, namely the current ratio, test acid ratio and cash ratio financial position are said to be liquid. Solvability ratio is the ratio of debt to equity and debt to asset ratio of the company's financial position can be said to be solvable. The profitability ratio is the gross margin ratio, the net margin ratio and the rate of ROI, the company is said to be profit. And the results of the assessment or analysis of the company's health level are said to be healthy
\end{abstract}

Keywords: Financial reports, ratio analysis, company soundness. 
PRIMANOMICS : JURNAL EKONOMI DAN BISNIS - VOL. 17. NO. 2 (2019)

Versi Online Tersedia di : https://jurnal.ubd.ac.id/index.php/ds

| 1412-632X (Cetak) | 2614-6789 (Online) |

\section{PENDAHULUAN}

Dengan keadaan sekarang ini, dimana persaingan ketat dibidang perekonomian sudah mulai masuk ke negara Indonesia, maka jika seorang manajer perusahaan tidak memperhatikan faktor kesehatan keuangan dalam perusahaannya, mungkin saja akan terjadi kebangkrutan seperti yang telah dikemukakan sebelumnya. Analisis keuangan pada dasarnya ingin melihat prospek dan risiko perusahaan. Prospek bisa dilihat dari tingkat keuntungan (profitabilitas) dan risiko bisa dilihat dari kemungkinan perusahaan mengalami kesulitan keuangan atau mengalamikebangkrutan.

Pada saat ini pentingnya akuntansi keuangan makin disadari oleh setiap perusahaan. Selain untuk mengetahui keadaan keuangan suatu perusahaanjuga dapat digunakan sebagai pertimbangan untuk mengambil suatu keputusan ekonomi pada perusahaan. Analisis laporan keuangan juga sangat dibutuhkan oleh suatu perusahaan salah satunya adalah perusahaan jasa. Rasio menggambarkan suatu hubungan atau perimbangan (matematical relationship) antara suatu jumlah tertentu dengan jumlah yang lain, dan dengan menggunakan alat analisa berupa rasio ini akan dapat menjelaskan atau memberi gambaran kepada penganalisa tentang baik atau buruknya keadaan atau posisi suatu perusahaan terutama apabila angaka rasio tersebut dibandingkan angka rasio perbandingan yang digunakan sebagai standar(Andy, 2018).

Laporan keuangan tahunan yang dipublikasikan oleh PT Harapan Jaya Lestarindo belum menghitung rasio menurut penilaian dasar. Laporan keuangan perusahan tersebut baru menampilkan hasil dari perhitungan beberapa rasio dan masih ada rasio yang belum dihitung. Dalam laporan keuangan periode 2013 dan 2014 rasio yang sudah dihitung adalah Return On Equity, rasio lancar (Current Ratio), perputaran persediaan, perputaran total Asset Turn Over, rasio total modala sendiri terhadap aktiva yang belum dilakukan perhitungan oleh perusahaan(Andy, 2019). Perhuitungan dari rasio yang belum dihitung dharapkan dapat memberikan gambaran mengenai kinerja keuangan PT Harapan Jaya Lestarindo selama periode tahun 2013-2014.

\section{OBJEK DAN METODE PENELITIAN}

PT Harapan Jaya lestarindo adalah sebuah perusahaan jasa kontruksi yang melayani jasa pembangunan soccer field, Maintanance Gardening, Penghijauaan Putting Green,Civil dan Maintanace building. PT. Harapan Jaya Lestarindo atau lebih dikenal dengan sebutan PT.HJL didirikan pada tahun 2005, sebelum menjadi Perseroan Terbatas dan masih berbentuk CV yang bernama CV. Multi Flora Indah. Pada saat ini, PT Harapan Jaya Lestarindo menunjukkan perkembangan yang cukup baiik, hal ini dapat diliahat dari proyek-proyek yang ditangani semakin besar,bukan hanaya diwilayah JABODETABEK, namun juga diluar Pulau Jawa seperti Kalimantan,Sumatra,Sulawesi dan Papua. 
Lokasi perusahaan merupakan salah satu faktor penentu keberhasilan usaha, terutama menjamin efektifitas dan efisiensi operasional perusahaan. Oleh karena itu perusahaan perlu mempertimbangkan keadaan lokasi yang akan ditempati untuk mendirikan perusahaan,selain itu pemasaran pun dilakukan dengan menggunakan internet atau website yang rutin mengupdate kegiatan perusahaan sehingga customer yang sedang mencari atau membutuhkan kontraktor lapangan sepak bola yang handal dan terpercaya dapat dengn mudah mengakses via internet.

Kantor yang terletak di Jalan Raya Legok No.39 Kelapa Dua Tangerang. Perusahaan ini melakukan bisnis hampir diseluruh kota besar di inidonesia dengan membangun gedung-gedung sekolah bertaraf internasional di Indonesia yang didukung oleh jaringan luas, profesionalisme kerja atas setiap pelayanan serta garansi/jaminan dalam setiap pekerjaan yang dikerjakan, memberi jasa yang berkwalitas, konsisten dan memiliki nilai tambah demi mencapai tujuan bersama. Di dukung dengan tim kerja yang solid, berkompetensi tinggi di bidangnya yang sudah teruji dalam menangani berbagai macam proyek/pekerjaan lapangan sepak bola maupun landcape . PT HJL bekerja dengn prinsip kemitraan dimana kepuasan mitra adalah segalanya tanpa menghiraukan tujuan utama dari kegiatan usaha itu sendiri (Value Of Money).

Setiap perusahaan pasti memiliki visi. Begitu juga dengan PT Harapan Jaya Lestarindo. Adapun visi dari perusahaan adalah sebagai berikut;

1. Memperoleh laba yang meningkat dari tahun ke tahun.

2. Memperluas pangsa pasar

3. Memberikan kualitas pelayanan yang terbaik kepada konsumen.

Visi disertai juga denaga misi sebagai penunjang yaitu:

1. Kami berada dalam bidang usaha general contraktor dan suolier melalui pengembangan dan pemusatan sumber daya manusia.

2. Menyediakan jasa yang mempunyai kualitas yang sedemikian rupa untuk menciptakan kepuasaan pelanggan.

3. Mendorong dan mengoptimalkan pertumbuhan perusahaan.

\section{METODOLOGI PENELITIAN}

Strategi penelitian yang dilakukan oleh peneliti merupakan penelitian deskriptif dan komparataif. Strategi ini disesuaikan dengan tujuan yang ingin peneliti capai. Dengan strategi deskriptif peneliti ingin menjelaskan kepada pembaca bagaimana analisis laporan keuangan untuk menilai tingkat kesehatan pada perusahaan kontruksi. Kemudian dengan strategi komparatif, peneliti ingin mengetahui apakah subjek peneliti ini telah melakukan pembukuan atas pendapatannya sesuai dengan standar yang ada. Oleh karena itu di PT.HJL dengan standar yang berlaku (PSAK). Metode penelitian yang diterapkan adalah kasus. Metode studi kasus adalah penelitian status subjek penelitian ini data yang adan diteliti spesifik pada pembangunan. 
PRIMANOMICS : JURNAL EKONOMI DAN BISNIS - VOL. 17. NO. 2 (2019)

Versi Online Tersedia di : https://jurnal.ubd.ac.id/index.php/ds

| 1412-632X (Cetak) | 2614-6789 (Online) |

Menurut sumbernya, data tersebut terdiri atas data sekunder. Data sekunder diperoleh dengan menganalisa dokumen-dokumen transaksi yang ada.

\section{A. Waktu dan Tempat Penelitian}

Dalam penelitian ini penulis mengambil kasus yang terjadi pada PT. Harapan Jaya Lestarindo yang beralamat di Jl.Raya Legok No.39 Kelapa Dua Tangerang.

\section{B. Populasi dan Sampel}

Dalam menganalisis laporan keuangan untuk menilai tingkat kesehatan keuangan perusahaan konstruksi di Indonesia diperlukan papulasi dan sampel. Untuk mempermudan dalam menganalisis laporan keuangan sebagai perwakilanperusahaan jasa konstruksi di Indonesia maka diperlukan sampel. Populasi dalam penelitian ini berjumlah 2 laporan keuangan PT Harapan Jaya Lestarindo yaitu dari tahun 2013 dan 2014. Sedangkan sampel yang diambil dalam penelitian ini adalah 3 rasio keuangan yang akan diteliti dari masingmasing laporan keuangan. Jadi total sampel yang digunakan adalah 6 sampel.

\section{Variabel Penelitian}

Pada dasarnya data yang diperlukan dalam penelitian ini dapat dikelompokkan menjadi 2 variabel yaitu:

1. variabel pertama (X1) adalah seluruh variabel bebas yang mempengaruhi kinerja keuangan perusahaan usaha jasa konstruksi. Variabel ini terdiri dari pendapatan baik yang berasal dari kegiatan operasional maupun non operasional dan seluruh beban-beban yang dikeluarkan perusahaan untuk memperoleh pendapatan tersebut.Gambaran tentang lukuiditas perusahaan,gambaran solbvabilitas perusahaan, dan gambaran profitabiilitas perusahaan.

Variabel-variabel ini diduga berpengaruh terhadap peningkatan kinerja perusahaan jasa konstruksi.

2. Variable kedua $(Y)$ yaitu kinerja keuangan perusahaan usaha jasa konstruksi Disamping itu, beban pajak juga menjadi variabel penelitian untuk mengetahui pengaruh penerapan PP 51/2008 jo. PP 40/2009 terhadap perusahaan usaha jasa konstruksi yang terdaftar pada BEI.

\section{Instrumen Penelitian}

Teknik pengumpulan data pada penelitian ini dengan menggunakan dokumentasi. Menurut Sugiyono (2015:329) dokumen merupakan catatan peristiwa yang sudah berlalu. Data dokumen yang digunakan dalam penelitian ini adalah berupa laporan keuangan PT.Harapan Jaya Lestarindo tahun 2013-2014.

Metode analisis data dalam penelitian ini untuk rasio likuiditas terdiri dari: rasio lancar (current ratio), rasio cepat (quick ratio). Untuk rasio solvabilitas terdiri dari gross profit margin ( margin laba kotor), Net profit Margin ( Margin Laba Bersih), Return On Equity( Pengembalian Ekuitas). Dan rasio rata-rata untuk memnentukan sehat atau tidaknya posisi keuangan suatu perusahaan pada periode tertentu 
dengan rasio rata-rat industrinya pada periode yang bersangakutan disebut dengan metode industri.yang secara sistematis dapat dilaukan dengan cara sebagai berikut:

a. Untuk rasio likuidasi aktivitas, profitabilitas dan nilai pasar

$\mathrm{Rk}_{\mathrm{it}} \geq$ kategori sehat

b. Untuk rasio leverage

$\mathrm{Rk}_{\mathrm{it}} \leq \ldots \ldots \ldots . .$. kategori sehat.

Keterangan :

$\mathrm{Rk}_{\mathrm{it}}=$ rasio keuangan perusahaan 1 pada periode $\mathrm{t}$

$\mathrm{Rk}_{\mathrm{it}}=$ rasio keuangan rata-rata industri pada periode $\mathrm{t}$.

Perhitungna rata-rata industri pada analisis rasio keuangan dapat dilakukan dengan metode rata-rata aritmatika dan rata-rata tertimbang.

\section{HASIL DAN PEMBAHASAN}

\section{Hasil Penelitian Deskripsi}

Pada saat ini pentingnya akuntansi keuangan makin disadari oleh setiap perusahaan. Selain untuk mengetahui keadaan keuangan suatu perusahaan juga dapat digunakan sebagai pertimbangan untuk mengambil suatu keputusan ekonomi pada perusahaan. Analisis laporan rasio keuangan juga sangat dibutuhkan oleh suatu perusahaan salah satunya adalah perusahaan jasa.

Untuk mendapatkan gambaran posisi keuangan dan hasil yang telah di capai perusahaan dalam suatu periode tertentu maka di perlihatkan laporan keuangan dalam bentuk neraca dan laporan laba rugi yang dimaksud untuk mengtahui perubahan modal dan kekayaan perusahaan pada periode tertentu. Perubahan ini mungkin terjadi pada aktiva lancar atau aktiva tetap, sedangkan pada laporan laba rugi dimaksudkan untuk mengetahui kegiatan perusahaandalam memperoleh keuntungan dan kaberhasilan dalam mencapai tujuan yang di gariskan perusahaan.

Rasio menggambarkan suatu hubungan atau perimbangan (matematical relationship) antara suatu jumlah tertentu dengan jumlah yang lain, dan dengan menggunakan alat analisa berupa rasio ini akan dapat menjelaskan atau memberi gambaran kepada penganalisa tentang baik atau buruknya keadaan atau posisi suatu perusahaan terutama apabila angaka rasio tersebut dibandingkan angka rasio perbandingan yang digunakan sebagai standar. Ada beberapa cara untuk menilai kondisi kesehatan persahaan dengan mengguanakan analisis kinerja keuangan. Namun dalam hal ini penulis hanya analisis rasio likuiditas, rasio solvabilitas dan rasio profitabilitas perusahaan. Karena menyangkut kelangsu hidup perusahaan penilaian prestasi perusahaan bagi pihak manajemen .kushurey u untuk mengukur profitabilitas perusahaan merupakan salah satu faktor penting untuk mengetahui tingkat efisiensi perusahaan. Tingginya profitabilitas perusahaan lebih penting dibanding laba maksimal yang dicapai perusahaan 
PRIMANOMICS : JURNAL EKONOMI DAN BISNIS - VOL. 17. NO. 2 (2019)

Versi Online Tersedia di : https://jurnal.ubd.ac.id/index.php/ds

| 1412-632X (Cetak) | 2614-6789 (Online) |

pada setiap periode akuntansi. Untuk itu setiap pemimpin perusahaan dituntut agar mampu mengelola manajemen perusahaan dengan baik agar dapat mencapai tingkat efisiensi yang optimal dari penggunaan modalnya.

Tujuan dan sasaran melakukan evaluasi adalah untuk mengatahui tingkat kesehatan perusahaan selama dua tahun terakhir yaitu tahun 2013 dan tahun 2014. Apakah perusahaan mengalami perkembangan yang menguntungkan, menurun dan bahkan tidak mengalami perkembangan yang signifikan, perusahaan apakah bisa dikatakan sehat atau tidak sehat, dan disamping itu untuk memudahkan perusahaan dalam mengambil keputusan keuangan.

2. Data Penelitian

Untuk mengetahui rasio keuangan untuk menilai tingkat kesehatan suatu perusahaan maka data-data yang dibutuhkan adalah laporan keuangan perusahaan yang salah satunya adalah laporan neraca. Dalam data ini penulis mempunyai data laporan neraca tahun 2013 dan 2014 di PT Harapan Jaya Lestarindo dari bagian keuangan perusahaan tersebut. Adapun data yang diperoleh adalah sebagai berikut:

\section{A. Laporan Neraca}

Laporan Nearca Tahun 2013 dan 2014

PT Harapan Jaya Lestarindo

\begin{tabular}{|l|l|l|}
\hline Bangunan & 1.587 .045 .600 & 1.587 .045 .600 \\
\hline Tanah & 1.737 .492 .665 & 1.737 .492 .665 \\
\hline Kendaraan & 275.400 .000 & 417.000 .000 \\
\hline $\begin{array}{l}\text { Peralatan Kantor } \\
\text { Peralatan } \\
\text { Konstruksi Aktiva }\end{array}$ & 21.747 .440 & 29.600 .000 \\
\hline $\begin{array}{l}\text { Jumlah } \\
\text { Tetap }\end{array}$ & 232.900 .000 & 351.000 .000 \\
\hline TOTAL AKTIVA & 4.854 .858 .709 & 4.122 .138 .265 \\
\hline PASSIVA & & $5.290 .513,59$ \\
\hline Hutang Lancar & 237.992 .000 & \\
\hline Hutang Usaha & 18.200 .000 & 245.000 .000 \\
\hline Hutang Karyawan & 618.900 .810 & 661.025 .344 \\
\hline Hutang Biaya & 875.022 .000 & 926.525 .344 \\
\hline $\begin{array}{l}\text { Jumlah Hutang } \\
\text { Lancar }\end{array}$ & 1.466 .325 .002 & 1.562 .583 .336 \\
\hline Modal & & \\
\hline Modal Disetor & & \\
\hline
\end{tabular}




\begin{tabular}{|l|l|l|} 
Laba Ditahan & 475.664 .545 & 525.182 .400 \\
\hline $\begin{array}{l}\text { Laba/Rugi } \\
\text { Berjalan }\end{array}$ & 2.004 .725 .111 & 2.276 .222 .505 \\
\hline jumlah Modal & 3.946 .714 .758 & 43.639 .888 .241 \\
\hline TOTAL PASSIVA & 4.821 .736 .758 & 5.290 .513 .585 \\
\hline
\end{tabular}

\section{Sumber: PT Harapan Jaya Lestarindo}

\section{B. Laporan Laba/Rugi}

Selain laporan neraca untuk menganalisis keuangan perusahaan dibutuhkan juga laporan laba/rugi, dalam hal ini penulis memperoleh data laporan laba/rugi PT Harapan Jaya Lestarindo tahun 2013 dan 2014 dari bagiaan keuangan perusahaan.

Adapun data yang diperoleh sebagai berikut:

Laporan Laba/Rugi tahun2013 dan 2014

\begin{tabular}{|l|l|l|}
\hline \multicolumn{1}{|c|}{ Tahun } & 2013 & 2014 \\
\hline Pendapatan Konstruksi & 2.304 .911 .111 & 2.655 .264 .250 \\
\hline Pendapatan Lain-lain & 404.500 .000 & 525.235 .050 \\
\hline Jumlah Penapatan & 2.709 .411 .111 & 3.180 .499 .300 \\
\hline Biaya Usaha & 704.686 .000 & 904.276 .795 \\
\hline Laba Sebelum Pajak & 2.004 .752 .111 & 2.276 .222 .505 \\
\hline Pajak Penghasilan & 561.323 .631 & 637.342 .301 \\
\hline Laba Setelah Pajak & 1.443 .402 .480 & 1.638 .880 .204 \\
\hline
\end{tabular}

\section{Sumber : PT Harapan Jaya Lestarindo}

\section{Hasil Analisis Penelitian}

\section{Analisa Rasio pada PT Harapan Jaya Lestarindo}

Untuk mengukur kemampuan keuangan perusahaan dengan menggunakan analisa rasio likuidasi yang meliputi: current ratio, acid test ratio, cash ratio kemudian rasio solvabilitas yang meliputi ratio modal dengan aktiva dan ratio antara hutang dengan aktiva. Rasio solvabilitas meliputi: laba rasio dengan aktiva usaha, rate of ROI maka digunakan rumus sebagai berikut:

\section{Rasio Likuiditas}


PRIMANOMICS : JURNAL EKONOMI DAN BISNIS - VOL. 17. NO. 2 (2019)

Versi Online Tersedia di : https://jurnal.ubd.ac.id/index.php/ds

| 1412-632X (Cetak) | 2614-6789 (Online) |

Menurut Kasmir (2011:130)," rasio likuiditas atau sering juga disebut dengan nama rasio modal kerja merupakan rasio yang digunakan untuk mengukur seberapa likuidnya suatu perusahan.

Tingkat likuiditas perusahaan diukur dengan current ratio, acid ratio, dan cash ratio.berikut adalah perhitungan rasio likuidasi:

\section{a. Current Ratio}

Current ratio $=\underline{\text { Aktiva lancar }}$

Hutang lancar

Tahun $2013=\underline{967.151 .053}=1,106$ atau $110 \%$

875.022 .000

Tahun $2014=\underline{1.168 .375 .320}=1,261$ atau $126 \%$

926.525 .344

Analisis

Pada tahun 2013,current ratio PT Harapan Jaya Lestarindo 1,106 atau 110\% yang diperoleh dengan perbandingan aktiva lancar sebesar 967.151.053 dengan hutang lancar 875.022.000. Hal ini berarti setiap Rp 1, hutang lancar belum bisa dijamin oleh aktiva lancar sebesar Rp 110.

Pada tahun 2014,current ratio mengalami kenaikan dari 110\% pada tahun 2013 menjadi $126 \%$ pada tahun 2014 yang diperoleh dengan perbandingan aktiva lancar sebesar Rp1.168.375.320 dengan hutang lancar Rp 926.525.344. Ini berarti setiap Rp 1, hutang lancar belum bisa dijamin aktiva lancar sebesar Rp 126.

\section{b. Acid test ratio}

Acid test ratio $=\underline{k a s}+$ efek + piutang

Hutang lancer

Thn $2013=\underline{729.751 .053+237.400 .000}$

875.022 .000

Thn 2014 $=\frac{830.988 .654+337.386 .666}{926.525 .344}$

926.525 .344

$=1,261$ atau $126 \%$

c. Cash ratio

Cash ratio $=\underline{\text { kas }}+$ efek

Hutang lancer

Tahun $2013=\underline{729.751 .053}=0,833$ atau $83 \% \quad 875.000 .000$

Tahun $2014=\underline{830.988 .654}=0,896$ atau 89\% 926.525 .344

\section{ANALISIS}

Pada tahun 2013 cash ratio PT Harapan Jaya Lestarindo sebesar 83\% yang diperoleh dari perbandingan kas(bank) sebesar Rp 729.751.053 dengan hutang lancar sebesar Rp 
875.022.000. Hal ini berarti setiap Rp 1 hutang lancar dapat dijamin oleh cash asset sebesar $\operatorname{Rp} 0,896$.

Pada tahun 2014, cash ratio PT Harapan Jaya Lestarindo mengalami kenaikan dari 83\% pada tahun 2013 menjadi 89\% pada tahun 2014, dengan perbandingan kas(bank) sebesar Rp 830.988.654 dengan hutang lancar sebesar Rp 926.525.344. Ini berarti setiap Rp 1, hutang lancar dapat dijamin oleh cash asset sebesar Rp 0,896.

$$
=1,106 \text { atau } 110 \%
$$

Rasio likuiditas tahun 2013 dan 2014

\begin{tabular}{|l|l|l|c|}
\hline Tahun & $\mathbf{2 0 1 3}$ & $\mathbf{2 0 1 4}$ & naik (turun ) dalam \% \\
\hline Current Ratio & $110 \%$ & $126 \%$ & $16 \%$ \\
\hline Acid test ratio & $110 \%$ & $126 \%$ & $16 \%$ \\
\hline Cash Ratio & $83 \%$ & $89 \%$ & $6 \%$ \\
\hline
\end{tabular}

Sumber : diolah dari laporan keuangan PT Harapan Jaya Lestarindo

Dari tabel di atas merupakan hasil perhitungan current ratio PT Harapan Jaya Lestrindo pada tahun 2013 dan 2014, current ratio menunjukkan sejauh mana aktiva lancar dapa digunakan untuk membayar hutang lancar. Semakin besar perbandingan aktiva lancar denagn hutang lancar, semakin tinggi kemampuan perusahan membayar hutang lancarnya. Standar umum yang digunakan adalah 2:1 atau 200\% untuk perusahaan komersil dan industri, namun sudah dianggap baik untuk perusahaan jasa menggunakan standar rasio 1:1 atau 100\%.berdasarkan tabel IV current ratio pada tahun 2014 amsing adalah 126\% artinya Rp 1,- hutang lancar akan dijamin dengan Rp 1,3.aktiva lancar, sehingga posisi keuanagn perusahaan tersebut dapat dikatakan likuid.

Perhitungan acid test ratio 2014 sebesar 126\%. Acid test ratio digunakan untuk menunjukkan kemampuan perusahan dalam memenuhi atau membayar kewajiban atau hutang lancar dengan aktiva lancar tanpa memperhitungkan nilai persediaan. Hal ini dilakukan karena persediaan dianggap memerlukan waktu yang relatif lebih lama untuk diuangkan, apabila perusahaan membutuhkan dana cepat untk membayar kewajiban dibandingkan dengan aktiva lancar lainnya. Untuk acid test ratioukuran berdasarkan prinsip hati-hati standar rasio umum adalah 100\% atau 1:1 dianggap sanagat baik didalam perusahaan apabila kurang maka dianggap kurang baik. Acid test ratio pada tahun 2014 adalh 126\% artinya Rp 1,- hutang lancar dijamin dengan $\mathrm{Rp} \mathrm{1,3,-}$ aktiva lancar sehingga posisi keuangan perusahaan dapat dikatakan likuid.

Perhitungan cash ratio pada tahun 2014 adalah 89\%, cash ratio merupakan alat untuk mengukur seberapa besar uang kas yang tersedia untuk membayar hutang. Hal ini dapat ditunjukkan dengan tersedianya dana kas atau setara dengan kas seperti rekening dan giro. Rasio ini menunjukkan kemampuan sesungguhnya bagi perusahaan untuk membayar hutang lanacar, tidak terdapat standar khusus pada cash ratio sehingga penilaiannya tergantung kebijakan perusahaan. Standar umum 
PRIMANOMICS : JURNAL EKONOMI DAN BISNIS - VOL. 17. NO. 2 (2019)

Versi Online Tersedia di : https://jurnal.ubd.ac.id/index.php/ds

| 1412-632X (Cetak) | 2614-6789 (Online) |

rata-rata industri yang diguamnakan dalam $50 \%$. Hasil perbandingan pada tabel VI cash ratio tahun 2014 adalah $89 \%$ yang berarti setiap Rp.1,- hutang lancar dijamin dengan Rp.0,9,- kas, maka posisikeuangan perusahaan dapat dikatakan likuid.

Current ratio pada tahun 2013 dan 2014 masing-masing adalah 110\% dan 126\% yang artinya mengalami kenaikan sebesar $16 \%$. Dari hasil pertandingan acit test ratio pada tahun 2013 dan 2014 masing-masing adalah 110\% dan 126\% yang artinya mengalami peningkatan sebesar 16\%. cash ratio pada tahun 2013 dan 2014 masing-masing adalah $83 \%$ dan $89 \%$ yang artinya mengalami kenaikan sebesar 6\%, maka dari hasil analisa rasio likuiditas diatas dapat dikatakan bahwa posisi keungan perusahaan likuid.

2. Rasio solvabilitas

Menurut Fahmi (2011:174) " solvabilitas merupakan gambaran kemampuan suatu perusahaan dalm memenuhi dan menjaga kemampuannya untuk selalu mampu memenuhi kewajibannya dalam membayar utang secara tepat waktu".

Solvabilitas perusahaan dapat diukur mengguknak rumus rasio solvabilitas, dalam hal ini rasio siolvabiritas hanya dilihat dari ratio hutang dengan modal sendiri dan ratio antara hutang dengan aktiva. Berikut adalah perhitungan ratio solvabilitas:

a. Rasio hutang dengan modal sendiri

Rasio huatng dengan modal sendiri $=$ Total hutang Modal sendiri

Tahun $2013=\underline{875.022 .000}=22,1 \%$ 3.946 .714 .758

Tahun $2014=\frac{926.525 .344}{4.363 .988 .241}=21,2 \%$

Pada tahun 2013, rasio hutang modal sebesar 22,1\% yag diperoleh dari perbandingan total hutang sebesar Rp 875.022.000 dengan penjualan sebesar Rp 3.946.714.75. ini berarti perusahaan baru bisa menutupi hutang sebesar 22.1\% Pada tahun 2014 terjadi penurunan dari 22.1\% pada tahun 2013 menjadi sebesar $21.2 \%$ pada tahun 2014 yang diperoleh dari perbandingan total hutang sebesar Rp 926.525.344 denagn penjuaan sebesar 4.363.988.241.ini berarti prusahaan baru bisa menutupi hutang sebesar $21.2 \%$.

b. Ratio antara hutang dengan aktiva

Ratio hutang dengan aktiva $=\underline{\text { total hutang }}$

Jumlah aktivitas

Tahun $2013=\underline{875.022 .000}=18,1 \%$

4.821 .736 .758

Tahun $2014=\underline{926.525 .344}=17,5 \%$

5.290 .513 .585

Dikarenakan Debt Ratio yang digambarkan oleh PT Harapan Jaya Lestarindo semakin kecil, maka hutang yang dimiliki perusahaan pun semakin kecil dan ini beresiko financial bahwa PT Harapan Jaya Lestarindo mengembalikan pinjaman yang semakin kecil pula. 
Tabel

Rasio Solvabilitas tahun 2013 dan 2014

\begin{tabular}{|c|c|c|c|}
\hline Tahun & $\mathbf{2 0 1 3}$ & $\mathbf{2 0 1 4}$ & Naik (Turun) dalam \% \\
\hline $\begin{array}{c}\text { Rasio hutang dengan modal } \\
\text { sendiri }\end{array}$ & $22,10 \%$ & $21,20 \%$ & $0,9 \%^{*}$ \\
\hline $\begin{array}{c}\text { Rasio antar total hutang dengan } \\
\text { aktiva }\end{array}$ & $18,10 \%$ & $17,50 \%$ & $0,6 \%^{*}$ \\
\hline
\end{tabular}

Ket: $\left(^{*}\right)$ menunjukkan penurunan

Dari tabel di atas merupakan hasil pengolahan rasio hutang dengan modal sendiri pada tahun 2014 adalah 21,2\%. Rasio hutang dengan modal sendiri ini membandingkan total utang dengan modal sendiri. Rasio ini digunakn untuk mengetahui berapa bagian setiap rupiah dari modal sendiri yang digunakan untuk menjamin utang. Semakin besar rasio hutang dengan modal sendiri maka semakin tidak menguntungkan bagi para kreditur., karena jumlah modal sendiri terhadap utang semakin kecil. Standar umum rata-rata industri yang digunakan adalah $100 \%$. Nilai rasio diatas $100 \%$ dinilai sangat berbahaya bagi kreditur karaena jumlah utang lebih besar daripada modal sendiri. Rasaio hutang dengan modal sendiri pada tahun 2014 adalah $21,2 \%$ artinya perusahaan dibiayai oleh hutang sebesar 21,2\% pada tahun 2014 maka dapat dikatakan posisi keuangan perusahaan solvabel.

Rasio antara hutang dengan aktiva pada tahun 2014 adalah 17,5\%. Rasio antar hutang dengan aktiva merupakan rasio yang digunakan untuk mengukur perbandingan antara total hutang dengan total aktiva dengan kata lain seberapa besar aktiva oerusahaan dibiayai oleh hutang. Para kreditur lebih menyukai rasio utang yang lebih rendah ,sebab semakin rendah rasio utang perusahaan yang diberi kredit akan semakin besar tingkat keamanan yang didapat kreditur pada waktu likuidasi. Standar rasio umum rata-rata industri adalah 100\% dan hasil perhitungan rasio pada tahun 2014 adalah $17,5 \%$, maka artinya $17,5 \%$ aktiva dibiayai dengan hutang dan $82,5 \%$ dibiayai dengan modal sendiri, maka pasisi keuangan perusahaan dapat dikatakan solvabel.

Dari hasil perbandingan rasio antar hutang dengan modal sendiri pada tahun 2013 dan 2014 masing-masing adalah 22,1\% dan 21,2\% maka artinya mengalami penurunan sebesar $0,9 \%$.dari hasil perbandingan rasio antar hutang dengan total aktiva pada tahun 2013 dan 2014 masing-masing 18,1\% dan 17,5\%5 maka artinya mengalami penurunan sebesar 0,65 . Penurunan rasio ini berarti baik bagi perusahaan karena semakin kecil pula hutang perusahaan, shingga dari hasil analisa solvabilitas diatas dapat dikatakan posisi keuanagan perusahaan solvabel karenaperusahan mampu memenuhi hutang-hutang jagka pendek maupun jangka panjangnya. 
PRIMANOMICS : JURNAL EKONOMI DAN BISNIS - VOL. 17. NO. 2 (2019)

Versi Online Tersedia di : https://jurnal.ubd.ac.id/index.php/ds

| 1412-632X (Cetak) | 2614-6789 (Online) |

3. Rasio Profitabilitas

Rasio profitabilitas adalah rasio yang digunakan untuk menilai kemampuan perusahaan dalam mencari keuntungan. Profitabilitas perusahaan dapat diukur mengguanakam rumus net margin ratio, perputaran aktiva usaha dan rate of ROI. Berikut adalah perhitungannya:

a. Gross margin ratio $=\underline{\text { laba kotor }}$

$$
\text { Penjualan }
$$

Tahun $2013=\underline{2.004 .725 .111}=74 \%$

$$
\text { 2.709.411.111 }
$$

Tahun $2014=\underline{2.276 .222 .505}=71,5 \%$

$$
3.180 .499 .300
$$

Pada tahun 2013 Gross margin ratio PT Harapan Jaya Lestarindo 74\% yang di perolehdengan perbandingan laba kotor sebesar 2.004.725.111 dengan penjualan 2.709.411.111. Dengan standar umum rata-rat industri adalah $30 \%$.

Pada tahun 2014 Gross margin ratio mengalami penurunan dari 74\% pada tahun 2013 menjadi 71,5\% pada tahun 2014 yang diperoleh dengan perbandingan laba kotor sebesar Rp 2.276.222.505 dengan penjualan sebesar Rp 3.180.499.300. Hal ini berarti mengalami penurunan $2,5 \%$

\section{b. Net Margin Ratio}

Net margin ratio $=\underline{\text { laba usaha }}$

$$
\text { Penjualan }
$$

Tahun $2013=\underline{1.433 .402 .408}=53,2 \%$

$$
\text { 2.709.411.111 }
$$

Tahun $2014=\underline{1.638 .880 .204}=51,6 \%$

$$
\text { 3.180.499.300 }
$$

Pada tahun 2013 Net margin ratio PT Harapan Jaya Lestarindo sebesar 53,2\% yang diperoleh laba usaha sebesar Rp 1.433.402.408 dengan penjualan 2.709.411.111. Pada tahun 2014 mengalami penurunan dari 53,2\% pada tahun 2013 menjadi 51,6\% pada tahun 2014 yang diperoleh dari laba usaha sebesar Rp 1.638.880.204 dengan penjualan sebesar $\operatorname{Rp}$ 3.180.499.300. Dengan kata lain setiap Rp 1.penjualan menghasilkan laba Rp 5,- . Hal ini mengalami penurunan sebesar 1,7\%.

\section{c. RATE Of ROI}

Rate Of ROI=LabaBersih(sblm pjk)

$$
\text { Jumlah aktiva usaha }
$$

Tahun $2013=\underline{2.004 .725 .111}=41,6 \%$

$$
4.821 .736 .758
$$

Tahun $2014=\underline{2.276 .222 .505}=43 \%$

5.290.413.585 
Pada tahun 2013 Rate of ROI PT Harapan Jaya Lestarindo sebesar 41,6\% yang di peroleh dari laba bersih sebesar Rp 2.004.725.111 dengan jumlah aktiva usaha sebesar Rp 4.821.736.758.

Pada tahun 2014 Rate Of ROI mengalami peningkatan dari 41,6\% pada tahun 2013 menjadi 43\% pada tahun 2014 yang di peroleh dengan laba bersih sebesar Rp 2.276.222.505 dengan jumlah aktiva usaha sebesar 5.290.413.585.hal ini berarti mengalami kenaikan sebesar $1,4 \%$.

Tabel

Rasio Profitabilitas tahun 2013 dan 2014

\begin{tabular}{|l|l|l|l|}
\hline \multicolumn{1}{|c|}{ Tahun } & \multicolumn{1}{c|}{$\mathbf{2 0 1 3}$} & \multicolumn{1}{c|}{$\mathbf{2 0 1 4}$} & \multicolumn{2}{c|}{ Naik ( Turun) Dalam \% } \\
\hline Gross margin ratio & $74 \%$ & $71,5 \%$ & $2,5 \%$ \\
\hline Net margin ratio & $53,2 \%$ & $51,6 \%$ & $1,7 \%$ \\
\hline Rate of ROI & $41,6 \%$ & $43 \%$ & $1,4 \%$ \\
\hline
\end{tabular}

Diolah dari PT Harapan Jaya Lestarindo

Dari hasil perbandingantabel di atas Gross margin ratio pada tahun 2014 adalah 71,5\%. Gross margin ratio merupakan rasio atau perimbangan antara Gross profit ( laba kotor) yang diperoleh perusahan dengan tingakt penjualan yang dicapai pada periode yang sama. Standar umum rata-rata industri adalah 30\%. Gross margin ratio pada tahun 2014 adalah 71,5\% maka dapat dikatakan bahwa perusahaan dalam keadaan profit.

Hasil pehitungan net margin ratiopada tahun2014 adalah 51,6\%. Net margin ratio digunakan untuk mengukur margin laba atas penjualan pada suatu periode tertentu. Standar umum rata-rata industri adalah $20 \%$. Net margin ratio perusahaan pada tahun 2014 sebesar 51,6\% atau dengan kata lain setiap Rp.1,- penjualan menghasilkan laab Rp 5,- maka dapat dikatakan kondisi perusahaan dalam keadaan profit.

Rate of ROI pada tahun 2014 sebesar 43\%. ROI merupakan rasio yang menunjukkna hasil atas jumlah aktiva yang digunakan dalam perusahaan, selain itu ROI juga merupakan satu ukuran tentang efektivitas manajemen dalam mengelola investasi. Standar umum rat-rat industri adalah 30\%. Perhitungan ROI tahun2014 menunjukkan rasio $43 \%$. Maka dapat dikatakan perusahaan dalam kondisi profit.

Dari perbandingan gross margin ratio pada tahun 2013 dan 2014 masing-masing adalah $74 \%$ dan $71 \%$ yang artinya mengalami penurunan sebesar $2,5 \%$. Net margin ratio pada tahun 2013 dan 2014 masing-masing adalah 53,2\% dan 51,6\% yangg artinya mengalmi penurunan sebesar 1,7\%. Dari hasil pebandinga rate of ROI pada tahun 2014 dan tahun 2013 masing-masing adalah 411,6\% dan 43\% artinya mengalami peningkatan sebesar 1,4\%, maka dari hasil analisa rasio profitabilitas diatas dapat dikatakan bahwa posisi keuangan perusahan profit. 
PRIMANOMICS : JURNAL EKONOMI DAN BISNIS - VOL. 17. NO. 2 (2019)

Versi Online Tersedia di : https://jurnal.ubd.ac.id/index.php/ds

| 1412-632X (Cetak) | 2614-6789 (Online) |

\section{KESIMPULAN}

Maka dari hasil analisa diatas dapat ddisimpulkan bahwa:

1. Ditinjau dari rasio likuiditas perusahaan dikatakan likuid karena berada diatas rata-rat umum industri, hal ini dapat dilihat dari current ratio pada tahun 2014 sebesar 126\% yang mengalami kenaikan jika dibanding tahun 2013 yaitu $110 \%$, acid test ratio pada tahun 2014 sebesar 126\% yang mengalami kenaikan jika diabnding tahun 2013 yaitu $110 \%$ dan cash ratio yang jugga mengalami pada tahun 2014 sebesar 89\% dan tahun 2013 hanya 83\%.Dari hasil analisis ratio likuiditas pasisi keuangan perusahaan dapat dikatakan likuid karena mampu mempengaruhi hutang jangka pendeknya.

2. Ditinjau dari rasio solvabilitas perusahaan dapat dikatakan solvabel karena berada dibaah rata-rata umum industri dilihat dari rasio antara hutang dengan modal sendiri pada tahun 2014 sebesar 21,2\% yang mengalami penurunan jika dibanding tahun 2013 yaitu 22,1\% dan rasio antar hutang dengan aktiva usaha pada tahun 2014 sebesar 17,5\% mengalami penurunan jika dibanding tahun 2013 yaitu 18,1\%.Dari hasil analisis solvabilitas posisi keuangan perusahaan dapat dikatakan solbvabel karena dapat memenuhi hutang jangaka pendek maupun jangak panjangnya

3. Dan ditinjau dari profitabilitas perusahaan dapat dikatakan profit karena diatas rat-rata umum industri hal ini dapat dilihat dari gross margin ratio pada tahun 2014 sebesar 71,5\% yang artinya mengalami penurunan jika dibandingkan tahun 2013 sebesar $74 \%$, net margin ratio pada tahun 2014 sebesar $51,6 \%$ yang juga mengalami penurunan jika dibandingkan tahun2013 sebesar 51,2\%. Rate of ROI pada tahun 2014 adalah 43\% artinya mengalami kenaikan jika dibandingkan tahun 2013 yaitu $41,6 \%$.Dari hasil analisis rasio rentabilitasnya perusahaan dapat dikatakan profit karena laba yang diperoleh mengalami peningkatan dari tahun ke tahun.

\section{Daftar Pustaka}

Andy. (2018). Pengaruh Return on Assets, Debt To Equity Ratio, Debt To Assets Ratio, Ukuran Perusahaan Dan Deferred Tax Expense Terhadap Tax Avoidance. Primanomics : Jurnal Ekonomi Dan Bisnis - Vol. 16. No. 2 (2018), 16(2).

Andy, M. M. (2019). Analysis Of Liquidity, Activity, Leverage, Financial Performance And Company Value In Food And Beverage Companies Listed On The Indonesia Stock Exchange. ECo-Fin Vol 1 No 1 (2019), 1(5), 52-58. https:/ / doi.org/10.14445/23939125/ijems-v6i5p109

Fahmi, Irham 2011. Analisa Laporan Keuangan" Lampulo : Alfabata Kasmir. 2011. Analisa Laporan Keuangan”. Jakarta : PT. Raja Grafindo Persada. Munawir. 2010. Analisa Laporan Keuangan". Yogyakarta: Liberty Yogyakarta. Fahmilrham. 2011. Analisis Kinerja Keuangan".Bandung : ALFABETA Jumungan. 2014 . Analisis Laporan Keuangan”.Jakarta PT Bumi Aksara. Munawir 2011. Analisis Laporan Keuangan “. Konsep dan aplikasi. Penerbit yogyakarta. 
Fahmi. 2011: 37 Definisi Rasio Keuangan" Bandung : Alfabeta.

S. Munawir 2012. Definisi Akuntansi" Yogyakarta : Liberty Yogyakarta.

Pura (2013). Definisi Akuntansi" hal 4. Jakarta.

Gorys Keraf (2010). Konsep Analisis" Terjemahan oleh Ali Akbar Yulianto. Jakarta Salemba Empat.

Komarrudin (2011) Definisi Analisis" Jakarta: Raja Wali Pers.

Ikatan Akuntan Indonesia (2011) karakteristik Laporan Keuangan" Jakarta.

Mahmud M Hanadie ( 2011) “ Analisis Rasio" Hal 77. Yogyakarta.

Sartono (2010) Definisi Rasio Keuangan". Jakarta :Ghalia Indonesia.

Darminto dan Julianty (2011:80) Manfaat Rasio Keuangan".Jakarta Rineka Cipta

Farah Margaretha (2011:113) Cara Menganalisis Rasio Keuangan", Penerbit Bumi Aksara, Jakarta.

Fahmi (2011:113) Cara Menganalisis Rasio Keuangan" Bandung: Alfabeta. Sawir, Agnes (2010) Analisis Kinerja Keuangan dan Perencanaan Keuangan Perusahaan. Penerbit: PT Gramedia Pustaka Utama Jakarta. Wild.John J. K.R. Subramanyam dan Robert F. Halsey. 2005. Analisis Laporan 